\title{
Productivity of Benggala grass (Panicum maximum) at different ages of oil palm
}

\author{
Achmad Fanindi ${ }^{1 *}$, Sajimin Sajimin ${ }^{1}$, Endang Sutedi ${ }^{1}$, Iwan Herdiawan ${ }^{1}$, and Harmini Harmini ${ }^{1}$ \\ ${ }^{1}$ Research Institute of Animal Production, Ciawi, Bogor 16002, Indonesia
}

\begin{abstract}
The study aimed to observe the cultivars of Benggala grass grown at different ages of oil palms. The research was conducted at the location of oil palm plantations at the Sei Putih, Deli Serdang, North Sumatra. The study used a Factorial Completely Randomized Block Design, using 3 replications, the first treatment was 2 oil palm planting ages, namely the age of fewer than 5 years and more than 5 years plus control (open space), while the second treatment was 5 cultivars of Benggala grass consisting of the Hamil, Riversdale, Natsuyutaka, Gatton and Petrie. The observed variables were morphological and reproductive characters. The results showed that the fresh and dry weight of the Benggala grass cultivars decreased at the age of oil palms less or more than 5 years when compared to the control $(P>0.05)$. Hamil and Riversdale cultivars had better yield than other cultivars $(P>0.05)$. The agronomic and reproductive characteristics of Benggala grass planted in the shade of oil palm showed a decrease when compared to open land. The decrease in Benggala grass production in shade indicates the need to assemble Benggala grass cultivars in oil palm shade.
\end{abstract}

\section{Introduction}

The oil palm plantation area can be used as a source of forage for livestock [1]. Palm oil plantations have the main limiting factor, namely low light intensity as the age of oil palm plant increases, causing a decrease in forage production in oil palm plantations [2]. Light limitations, resulting in the acclimatization of morphological forage to compensate for the low rate of photosynthesis per unit of leaf area through an increase in editorial ratios: roots, rods: leaves, and weight ratio of leaf area [3].

Forage that will be developed in the plantation area, must be tolerant of shade [4]. One of the forages, which is tolerant of moderate shade conditions is Benggala Grass (Panicum maximum) [5]. Tanzania cultivar bengal grass production ranges from 1.4 -2.4 tons/ha/harvest [6], With the content of $9.2-18.7 \%$ and digestibility $58.6-66.3 \%$ [7]. Some known Benggala grass cultivars are: A). Large type with plant height between 3.6 - $4.2 \mathrm{~m}$ like a Hamil cultivar, b). Moderate type with $1.5-2.5 \mathrm{~m}$ plant height such as Gatton and Common cultivars, and C) short types with $1.0 \mathrm{~m}$ plant height as in Sabi and Trichoglume cultivars [8].

To introduce Benggala Grass in oil palm plantations, it is necessary to test and select the cultivars of Benggala Grass to grow well on oil palm plantations. This selection is part of the breeding program in order to increase the productivity of Benggala Grass, because with breeding research can increase productivity of up to $63 \%$ [9].

\section{Methodology}

The study was conducted at the location of oil palm plantations in North Sumatra. The study used a randomized design of the factorial group with 3 replications, where the first factor was 3 ages of palm oil (location of Benggala grass planting) and the second factor was 5 Benggala grass cultivars (Panicum maximum). The age of oil palm used is less than 5 years (light intensity of 30\%) and more than 5 years (light intensity of 10\%), and without shade control (light intensity of $100 \%$ ). Benggala grass cultivar that was planted was 5 cultivars. Before being planted in the field, the pols were planted in a polybag for one month, then transferred to the field. Fertilization is done using urea fertilizer, TSP and KCL with a dose of $100 \mathrm{~kg} / \mathrm{ha} /$ year and manure with a dose of 10 tons/ha/year. Cutting is done at the age of 45 days of plant. The parameters observed are the morphological characters of plants, reproductive properties, forage production and seeds per spikelet (on average in 3 spikelet / clumps).

\footnotetext{
* Corresponding author: afanindi@gmail.com
} 


\section{Results and Discussion}

Grass productivity indicators are characterized by high forage weights. The weight of forage 5 Benggala grass cultivars, are presented in Table 1. The results of statistical analysis show that cultivars and palm oil agents have a significant effect $(\mathrm{P}>$ $0.05)$ in the weight of fresh and dry forage. The highest fresh and dry-dry weight is obtained on control $(100 \%$ light intensity), while fresh-weighted weight on palm oil is less and more than 5 years in a row equivalent with a light intensity of $30 \%$ and $10 \%$, not significantly different. Decreased fresh weight of $91.63 \%$ and $91.28 \%$ compared to fresh forage weight at the control site. The decrease in the weight of Benggala grass at low light intensity, indicating that the reduced light will cause a reduced photosynthesis rate, so it will inhibit the growth and production of plant biomass [10]. The decrease in forage weight at low light intensity also occurs in Paspalum, Arachis pinto $\underline{i}$ [11].

The highest fresh and dry forage at the control location and oil palm less than 5 years is found in Hamil cultivars with forage weight are $1,383.70 \mathrm{~g} /$ clumps and $101.63 \mathrm{~g} /$ clumps, while at the age of oil palm more than 5 years, fresh weight and the highest dry forage is obtained by the Riversdale cultivar.

Table1. Fresh weight (g/clump) 5 Benggala grass cultivars at different oil palm ages

\begin{tabular}{|l|l|c|c|c|c|}
\hline \multirow{2}{*}{ No } & \multirow{2}{*}{ Cultivar } & \multicolumn{3}{|c|}{ Age of oil palm } & \multirow{2}{*}{ Average } \\
\cline { 3 - 6 } & & control & $<5$ years & $>5$ years & \\
\hline 1 & Gatton & 588.15 & 59.07 & 81.85 & $243.02^{\mathrm{bc}}$ \\
\hline 2 & Petrie & 309.85 & 45.00 & 70.37 & $141.74^{\mathrm{c}}$ \\
\hline 3 & Natsuyutaka & 996.67 & 73.06 & 83.33 & $384.27^{\mathrm{ab}}$ \\
\hline 4 & Riversdale & 1145.56 & 91.54 & 92.04 & $443.05^{\mathrm{a}}$ \\
\hline 5 & Hamil & 1383.70 & 101.63 & 58.01 & $514.45^{\mathrm{a}}$ \\
\hline & Average & $884.79^{\mathrm{a}}$ & $74.06^{\mathrm{b}}$ & $77.12^{\mathrm{b}}$ & \\
\hline
\end{tabular}

Table 2. Dry weight (g/clump) 5 Benggala grass cultivars at different oil palm ages

\begin{tabular}{|l|l|c|c|c|c|}
\hline \multirow{2}{*}{ No } & \multicolumn{1}{|c|}{ Cultivar } & \multicolumn{3}{|c|}{ Age of oil palm } & \multirow{2}{*}{ Average } \\
\cline { 3 - 6 } & & Control & $<5$ years & $>5$ years & $19.40^{\mathrm{c}}$ \\
\hline 1 & Gatton & 77.73 & 12.19 & 11.43 & $33.78^{\mathrm{bc}}$ \\
\hline 2 & Petrie & 39.13 & 7.45 & 6.75 & $46.74^{\mathrm{abc}}$ \\
\hline 3 & Natsuyutaka & 121.57 & 11.91 & 17.12 & $58.98^{\mathrm{ab}}$ \\
\hline 4 & Riversdale & 143.86 & 15.97 & 7.73 & $68.42^{\mathrm{a}}$ \\
\hline 5 & Hamil & 176.85 & 20.69 & $10.93^{\mathrm{b}}$ & \\
\hline & average & $111.83^{\mathrm{a}}$ & $13.64^{\mathrm{b}}$ & & \\
\hline
\end{tabular}

Benggala's grass plant height is influenced by the age of oil plam and cultivar (Table 3). Benggala Grass on the control location shows higher plant height if compared to other locations. Whereas at the location of oil palm more than 5 years it shows higher plant height compared to the location of the plant less than 5 years. The height of shade-tolerant Benggala grass plants increased in 50\% (moderate) shade compared to no shade reported by Malaviya et al. [3] and Matta et al. [12] The highest high plant cultivars was Hamil cultivars. Hamil cultivars also have higher when compared to other cultivars in control, oil palm age less and over than 5 years. 
Table 3. Height (cm) 5 Benggala grass cultivars at different oil palm ages

\begin{tabular}{|l|l|c|c|c|c|}
\hline \multirow{2}{*}{ No } & \multicolumn{1}{|c|}{ Cultivar } & \multicolumn{3}{|c|}{ Age of oil palm } & \multirow{2}{*}{ Average } \\
\cline { 3 - 6 } & & Control & $<5$ years & $>5$ years & \\
\hline 1 & Gatton & 112.89 & 98.64 & 96.41 & $102.65^{\mathrm{b}}$ \\
\hline 2 & Petrie & 102.41 & 52.04 & 75.07 & $76.51^{\mathrm{c}}$ \\
\hline 3 & Natsuyutaka & 169.33 & 64.58 & 108.91 & $114.11^{\mathrm{ab}}$ \\
\hline 4 & Riversdale & 169.48 & 95.07 & 120.63 & $128.39^{\mathrm{a}}$ \\
\hline 5 & Hamil & 172.52 & 109.18 & 120.21 & $134.09^{\mathrm{a}}$ \\
\hline & Average & $145.33^{\mathrm{a}}$ & $83.90^{\mathrm{c}}$ & $104.22^{\mathrm{b}}$ & \\
\hline
\end{tabular}

Table 4. Number of tillers 5 Benggala grass cultivars at different oil palm ages

\begin{tabular}{|l|l|c|c|c|c|}
\hline \multirow{2}{*}{ No } & \multicolumn{1}{|c|}{ Cultivar } & \multicolumn{3}{|c|}{ Age of oil palm } & \multirow{2}{*}{ Average } \\
\cline { 3 - 6 } & & Control & $<\mathbf{5}$ years & $>\mathbf{5}$ years & \\
\hline 1 & Gatton & 51.19 & 14.76 & 9.85 & $25.27^{\mathrm{a}}$ \\
\hline 2 & Petrie & 46.89 & 13.30 & 9.81 & $23.33^{\mathrm{ab}}$ \\
\hline 3 & Natsuyutaka & 61.11 & 10.36 & 13.22 & $28.18^{\mathrm{a}}$ \\
\hline 4 & Riversdale & 50.74 & 17.14 & 7.93 & $25.27^{\mathrm{a}}$ \\
\hline 5 & Hamil & 27.22 & 13.28 & 7.15 & $15.88^{\mathrm{b}}$ \\
\hline & Average & $47.43^{\mathrm{a}}$ & $13.77^{\mathrm{b}}$ & $9.59^{\mathrm{b}}$ & \\
\hline
\end{tabular}

Table 5. Booting time (day after planting) 5 Benggala grass cultivars at different oil palm ages

\begin{tabular}{|l|l|c|c|c|c|}
\hline \multirow{2}{*}{ No } & \multirow{2}{*}{ Cultivar } & \multicolumn{3}{|c|}{ Age of oil palm } & \multirow{2}{*}{ Average } \\
\cline { 3 - 6 } & & Control & $<\mathbf{5}$ years & $>\mathbf{5}$ years & \\
\hline 1 & Gatton & 11.19 & 16.67 & 47.11 & $24.99^{\mathrm{a}}$ \\
\hline 2 & Petrie & 10.70 & 25.44 & 12.33 & $12.83^{\mathrm{b}}$ \\
\hline 3 & Natsuyutaka & 13.56 & 10.56 & 8.00 & $11.04^{\mathrm{b}}$ \\
\hline 4 & Riversdale & 18.41 & 15.78 & 11.45 & $31.06^{\mathrm{b}}$ \\
\hline 5 & Hamil & 40.44 & 40.09 & 12.65 & \\
\hline & Average & 18.86 & 21.71 & 12.41 & \\
\hline
\end{tabular}

The number of tillers is influenced by the type of cultivar and the age of the oil palm. The number of tillers at the control location was higher than the number of tillers in oil palms aged less and more than 5 years (table 4). A decrease in the number of tillers in selected shaded Benggala grass cultivars was also reported by [13] and [14]. Shade changes the intensity and quality of radiation in plants, and affects the potential number of tillers [15].

Age of booting and early flowering showed no difference $(\mathrm{P}<0.05)$ at the control site and in oil palms aged less and more than 5 years. The type of cultivar has a significant effect on booting age and early flowering), where the Petrie, Natsuyutaka and Riversdale cultivars faster than the Gatton and Hamil cultivars. 
Table 6. First flowering time (day after planting) 5 Benggala grass cultivars at different oil palm ages

\begin{tabular}{|c|c|c|c|c|c|}
\hline \multirow[t]{2}{*}{ No } & \multirow[t]{2}{*}{ Cultivar } & \multicolumn{3}{|c|}{ Age of oil palm } & \multirow[t]{2}{*}{ Average } \\
\hline & & Control & $<5$ years & $>5$ years & \\
\hline 1 & Gatton & 14.46 & 19.65 & 49.28 & $27.80^{\mathrm{b}}$ \\
\hline 2 & Petrie & 13.63 & 28.63 & 14.56 & $14.94^{c}$ \\
\hline 3 & Natsuyutaka & 17.67 & 9.44 & 9.04 & $9.04^{\mathrm{c}}$ \\
\hline 4 & Riversdale & 22.22 & 16.65 & 12.00 & $12.95^{\mathrm{c}}$ \\
\hline 5 & Hamil & 43.15 & 40.70 & 36.78 & $40.21^{\mathrm{a}}$ \\
\hline & Average & 22.23 & 23.01 & 17.72 & \\
\hline
\end{tabular}

Flowering time in Benggala grass cultivars was strongly influenced by planting location (Table 7). Benggala grass planted in control locations took longer to flowering when compared to Benggala grass planted in oil palm plantations aged less than 5 years and more than 5 years. Faster flowering in shade also occurs in soybeans [16]. The earlier flowering process occurs due to the presence of soluble proteins (phytochromes), where shaded environmental conditions can change the pigments (phytochromes) in shaded soybean plants into forms that initiate flowering induction [17]. Meanwhile, the Petrie, Natsuyutaka and Riversdale cultivars have a faster flowering age than the Gatton and Hamil cultivars.

Table 7. Flowering time (DAP) 5 Benggala grass cultivars at different oil palm ages

\begin{tabular}{|l|l|c|c|c|l|}
\hline \multirow{2}{*}{ No } & \multirow{2}{*}{ Cultivar } & \multicolumn{3}{|c|}{ Age of oil palm } & \multirow{2}{*}{ Average } \\
\cline { 3 - 6 } & & Control & $<\mathbf{5}$ years & $>\mathbf{5}$ years & \\
\hline 1 & Gatton & 19.30 & 25.93 & 27.70 & $34.31^{\mathrm{a}}$ \\
\hline 2 & Petrie & 19.48 & 24.57 & 15.00 & $14.69^{\mathrm{b}}$ \\
\hline 3 & Natsuyutaka & 21.63 & 10.78 & 11.00 & $10.80^{\mathrm{b}}$ \\
\hline 4 & Riversdale & 27.63 & 20.00 & 12.78 & $13.47^{\mathrm{b}}$ \\
\hline 5 & Hamil & 51.87 & 44.13 & 20.00 & $32.00^{\mathrm{a}}$ \\
\hline & Average & $27.98^{\mathrm{a}}$ & $21.08^{\mathrm{b}}$ & $14.10^{\mathrm{c}}$ & \\
\hline
\end{tabular}

Flag leaf length and flag leaf width (Tables 8 \& 9) are affected by planting location. The length of the flag leaf at the oil palm location is more than 5 years old, shorter than other locations, as well as the width of the flag leaf, which is narrower than other locations. Meanwhile, the length and width of the flag leaf of the Hamil cultivar are longer than other cultivars. The width of the flag leaf in each cultivar is more varied than the length of the flag leaf, this happens, because the width of the flag leaf is a physiological response of a plant to shade stress [18].

Leaf length and width (Tables 10 and 11) were strongly influenced by light intensity. One of the plant responses at low light intensity is leaf morphology which is wider and thinner when compared to plants at full light intensity. In this study, it was shown that planting location and cultivar had an effect on leaf length and width. The leaf length of the Benggala grass at the control location was longer than the other locations. Leaf length decreases with increasing age of oil palm. While the Hamil cultivar had longer leaf lengths when compared to other cultivars, the other 4 cultivars did not show any difference in leaf length. 
Table 8. Flag leaf length $(\mathrm{cm}) 5$ Benggala grass cultivars at different oil palm ages

\begin{tabular}{|l|l|c|c|c|c|}
\hline \multirow{2}{*}{ No } & \multirow{2}{*}{ Cultivar } & \multicolumn{3}{|c|}{ Age of oil palm } & \multirow{2}{*}{ Average } \\
\cline { 3 - 6 } & & control & $<\mathbf{5}$ years & $>\mathbf{5}$ years & \\
\hline 1 & Gatton & 11.85 & 9.00 & 16.20 & $9.35^{\mathrm{b}}$ \\
\hline 2 & Petrie & 12.37 & 16.37 & 9.50 & $9.58^{\mathrm{b}}$ \\
\hline 3 & Natsuyutaka & 16.63 & 2.28 & 6.30 & $6.30^{\mathrm{b}}$ \\
\hline 4 & Riversdale & 23.04 & 10.00 & 8.83 & $10.62^{\mathrm{b}}$ \\
\hline 5 & Hamil & 33.15 & 23.67 & 18.00 & $18.94^{\mathrm{a}}$ \\
\hline & Average & $19.41^{\mathrm{a}}$ & $8.46^{\mathrm{b}}$ & $5.01^{\mathrm{c}}$ & \\
\hline
\end{tabular}

Table 9. Flag leaf width $(\mathrm{cm}) 5$ Benggala grass cultivars at different oil palm ages

\begin{tabular}{|c|l|c|c|c|c|}
\hline \multirow{2}{*}{ No } & \multirow{2}{*}{ cultivar } & \multicolumn{3}{|c|}{ age of oil palm } & \multirow{2}{*}{ Average } \\
\cline { 3 - 6 } & & control & $<5$ years & $>5$ years & \\
\hline 1 & Gatton & 0.89 & 0.60 & 1.18 & $0.69^{\mathrm{b}}$ \\
\hline 2 & Petrie & 1.05 & 1.24 & 0.70 & $0.79^{\mathrm{b}}$ \\
\hline 3 & Natsuyutaka & 0.89 & 0.18 & 0.40 & $0.36^{\mathrm{c}}$ \\
\hline 4 & Riversdale & 1.45 & 0.66 & 0.53 & $0.66^{\mathrm{b}}$ \\
\hline 5 & Hamil & 2.69 & 2.11 & 1.00 & $1.60^{\mathrm{a}}$ \\
\hline & Average & $1.39^{\mathrm{a}}$ & $0.71^{\mathrm{b}}$ & $0.35^{\mathrm{c}}$ & \\
\hline
\end{tabular}

Table 10. Leaf length (cm) 5 Benggala grass cultivars at different oil palm ages

\begin{tabular}{|c|l|c|c|c|c|}
\hline \multirow{2}{*}{ No } & \multirow{2}{*}{ Cultivar } & \multicolumn{3}{|c|}{ age of oil palm } & \multirow{2}{*}{ Average } \\
\cline { 3 - 6 } & & control & $<\mathbf{5}$ years & $>\mathbf{5}$ years & \\
\hline 1 & Gatton & 20.07 & 30.89 & 6.54 & $19.17^{\mathrm{b}}$ \\
\hline 2 & Petrie & 19.11 & 2.44 & 27.00 & $16.19^{\mathrm{b}}$ \\
\hline 3 & Natsuyutaka & 31.74 & 11.00 & 10.00 & $10.58^{\mathrm{b}}$ \\
\hline 4 & Riversdale & 43.26 & 14.59 & 18.00 & $19.28^{\mathrm{b}}$ \\
\hline 5 & Hamil & 61.15 & 46.76 & 20.00 & $35.97^{\mathrm{a}}$ \\
\hline & Average & $35.067^{\mathrm{a}}$ & $18.937^{\mathrm{b}}$ & $6.707^{\mathrm{c}}$ & \\
\hline
\end{tabular}


Table 11. Leaf width $(\mathrm{cm}) 5$ Benggala grass cultivars at different oil palm ages

\begin{tabular}{|l|l|c|c|c|c|}
\hline \multirow{2}{*}{ No } & \multirow{2}{*}{ Cultivar } & \multicolumn{3}{|c|}{ Age of oil palm } & \multirow{2}{*}{ Average } \\
\cline { 3 - 6 } & & Control & $<\mathbf{5}$ years & $>\mathbf{5}$ years & \\
\hline 1 & Gatton & 1.12 & 0.90 & 1.44 & $0.95^{\mathrm{b}}$ \\
\hline 2 & Petrie & 1.26 & 1.53 & 0.90 & $0.96^{\mathrm{b}}$ \\
\hline 3 & Natsuyutaka & 1.28 & 0.50 & 0.22 & $0.80^{\mathrm{b}}$ \\
\hline 4 & Riversdale & 1.91 & 0.80 & 0.64 & $1.99^{\mathrm{a}}$ \\
\hline 5 & Hamil & 2.99 & 0.96 & 2.01 & $0.88^{\mathrm{b}}$ \\
\hline
\end{tabular}

Stem diameter and internode length were affected by the age of oil palm and Benggala grass cultivars (Tables 12 and 13). The stem diameter and internode length of the Benggala grass planted in the control locations were higher than other locations. Hamil cultivar, has the highest stem diameter when compared to other cultivars, which is $3.62 \mathrm{~cm}$, while the Natsuyutaka cultivar has a smaller value when compared to other cultivars, larger stem diameter in the Hamil cultivar, because morphologically this cultivar has a larger stem diameter when compared to other cultivars under normal conditions

Table 12. Stem diameter $(\mathrm{cm}) 5$ Benggala grass cultivars at different oil palm ages

\begin{tabular}{|l|l|c|c|c|c|}
\hline \multirow{2}{*}{ No } & \multirow{2}{*}{ Cultivar } & \multicolumn{3}{|c|}{ Age of oil palm } & \multirow{2}{*}{ Average } \\
\cline { 3 - 6 } & & Control & $<\mathbf{5}$ years & $>\mathbf{5}$ years & \\
\hline 1 & Gatton & 1.94 & 1.69 & 1.70 & $1.78^{\mathrm{cb}}$ \\
\hline 2 & Petrie & 1.70 & 0.17 & 1.59 & $1.16^{\mathrm{cd}}$ \\
\hline 3 & Natsuyutaka & 1.99 & 0.29 & 0.67 & $0.76^{\mathrm{d}}$ \\
\hline 4 & Riversdale & 1.93 & 1.20 & 1.21 & $1.96^{\mathrm{b}}$ \\
\hline 5 & Hamil & 3.49 & 2.92 & 1.00 & $3.62^{\mathrm{a}}$ \\
\hline & Average & $3.41^{\mathrm{a}}$ & $1.25^{\mathrm{b}}$ & $0.90^{\mathrm{b}}$ & \\
\hline
\end{tabular}

Table 13. Internode length (cm) 5 Benggala grass cultivars at different oil palm ages

\begin{tabular}{|c|l|c|c|c|c|}
\hline \multirow{2}{*}{ No } & \multirow{2}{*}{ Cultivar } & \multicolumn{3}{|c|}{ Age of oil palm } & \multirow{2}{*}{ Average } \\
\cline { 3 - 6 } & & Control & $<5$ years & $>5$ years & \\
\hline 1 & Gatton & 15.00 & 12.11 & 5.05 & $10.72^{\mathrm{ab}}$ \\
\hline 2 & Petrie & 17.04 & 13.07 & 6.07 & $12.06^{\mathrm{ab}}$ \\
\hline 3 & Natsuyutaka & 18.41 & 2.67 & 1.78 & $7.62^{\mathrm{b}}$ \\
\hline 4 & Riversdale & 27.33 & 8.78 & 4.23 & $13.45^{\mathrm{ab}}$ \\
\hline 5 & Hamil & 30.00 & 18.44 & 10.54 & $19.66^{\mathrm{a}}$ \\
\hline & Average & $21.56^{\mathrm{a}}$ & $11.02^{\mathrm{b}}$ & $5.53^{\mathrm{c}}$ & \\
\hline
\end{tabular}


Table 14. Seed weight (g/clump) 5 Benggala grass cultivars at different oil palm ages

\begin{tabular}{|l|l|c|c|c|c|}
\hline \multirow{2}{*}{ No } & \multirow{2}{*}{ Cultivar } & \multicolumn{3}{|c|}{ Age of oil palm } & \multirow{2}{*}{ Average } \\
\cline { 3 - 6 } & & Control & $<\mathbf{5}$ years & $>\mathbf{5}$ years & \\
\hline 1 & Gatton & 0.25 & 0.18 & 0.02 & $0.15^{\mathrm{ab}}$ \\
\hline 2 & Petrie & 0.25 & 0.09 & 0.00 & $0.11^{\mathrm{b}}$ \\
\hline 3 & Natsuyutaka & 0.43 & 0.06 & 0.00 & $0.16^{\mathrm{ab}}$ \\
\hline 4 & Riversdale & 0.87 & 0.00 & 0.00 & $0.29^{\mathrm{a}}$ \\
\hline 5 & Hamil & 0.07 & 0.00 & 0.05 & $0.04^{\mathrm{b}}$ \\
\hline & Average & $0.37^{\mathrm{a}}$ & $0.06^{\mathrm{b}}$ & $0.02^{\mathrm{b}}$ & \\
\hline
\end{tabular}

The highest seed production of Benggala grass was obtained at the control site, while at the location where oil palms were more than 5 years old had the lowest seed production. The cultivar with the highest production of pithy seeds was obtained by the Riversdale cultivar, while the lowest was the Hamil cultivar.

\section{Conclusion}

Benggala grass has decreased productivity, which is indicated by the low number of agronomic characters that support growth and productivity such as forage weight, number of tillers and plant height at the age of oil palm more or less than 5 years. Locations that can still be planted with Benggala grass are oil palm plantations that are less than 5 years old. Cultivars that still show good productivity and agronomic characteristics in oil palm plantations are the Hamil and Riversdale cultivars. The decline of Benggala grass cultivars in oil palm shade indicates that there is an influence of light intensity on the growth and productivity of Benggala grass, so it is necessary to look for cultivars that are tolerant of low light intensity (shade) through breeding activities.

\section{References}

1. B. Suwignyo, E. Baliarti, B. Suhartanto, M. Hamdani, A. Agus, I. G. S. Budisatria, Panjono, B. Guntoro, H. Trisakti, S. Bintara, Yuriadi, B. A. Atmoko, G. T. Yuwono. Pengembangan peternakan Berbasis Plasma Nutfah dan Kearifan Lof,al Mendukung Agroekologi Berkelaniutan (Fakultas Peternakan Universitas Gadjah Mada, Yogyakarta, 2016)

2. I. Ezenwa, O. A. Aribisala, M. E. Aken’ova, Tropical Grasslands 30, 414-417 (1996)

3. D. R. Malaviya, M. J. Baig, B. Kumar, and P. Kaushal, Revista de Biología Tropical 68, 563-572 (2020)

4. N. D. Purwantari, Wartazoa 26, 051-056 (2016)

5. C. C. Wong, Shade tolerance of tropical forages (Proceeding Workshop on Forages for Plantation Crops, Canberra (AUS), ACIAR, 1990)

6. M. D. Hare, S. Phengphet, T. Songsiri, N. Sutin, E. Stern, Tropical Grass-lands-Forrajes Tropicales 1, 87-89 (2013)

7. M. E. Siregar, M. Martawijaya, T. Herawati, Bulletin Lembaga Penelitian Peternakan 26 (1980)

8. Sajimin, E. Sutedi, N. D. Purwantari, B. R. Prawiradiputra, Prosiding Lokakarya Nasional Tanaman Pakan Ternak (Pusat Penelitian dan Pengembangan Peternakan, Badan Penelitiaan dan Pengembangan Pertanian, 2005)

9. Subandriyo et al, Prosiding Lokakarya Nasional Tanaman Pakan Ternak (Pusat Penelitian dan Pengembangan Peternakan, Badan Penelitiaan dan Pengembangan Pertanian, 2005)

10. J. Sirait, A. Tarigan, K. Simanihuruk, Junjungan, Produksi dan nilai nutrisi enam spesies hijauan pada tiga tingkat naungan di dataran tinggi beriklim kering (Prosiding Seminar Nasional Teknologi Peternakan dan Veteriner, Pusat Penelitian dan Pengembangan Peternakan, Badan Libang Pertanian, 2007)

11. R. S. Barro, A. C. Varella, G. Lemaire, R. B. Medeiros, J. C. Saibro, C. Nabinger, F. V. Bangel, I. J. Carassai, Zootec 41, 1589-1597 (2012)

12. P. M. Matta, S. M. Souto, P. F. Dias, A. A. Colombaria, B. C. Azevedo, M. S. Vieira, Archivos Latinoamericanos de Producción Animal 17, 097-102 (2009) 
13. D. M. Victor, L. Jank, B. Lempp, R. M. Simeão, M. D. V. Resende, M. C. Gonçalves, Rev. Ceres, Viçosa 62, 199-207 (2015)

14. D. S. C. Paciullo, C. A. M. Gomide, C. R. T. Castro, P. B. Fernandes, M. D. Müller, M. F. A. Pires, E. N. Fernandes, D. F. Xavier, Pesquisa Agropecuária Brasileira 46, 1176-1183 (2011)

15. O. Guenni, S. Seiter, R. Figueroa, Tropical Grasslands 42, 75-87 (2008)

16. Chairudin, Efendi, Sabaruddin, J. Floratek 10, 26 - 35 (2015)

17. L. T. Karamoy, Soil Environment 7, 65-68 (2009)

18. C. Hu, J. Rao, Y. Song, S. A. Chan, T. Tohge, B. Cui, PLOS ONE 15, 1-23 (2020) 